\title{
Cooperation amongst insurers on enhancing quality of care: precondition or substitute for competition?
}

\author{
Karel C. F. Stolper ${ }^{1 \star}$ (D), Lieke H.H.M. Boonen ${ }^{2}$, Frederik T. Schut ${ }^{3}$ (D) and Marco Varkevisser ${ }^{4}$ \\ ${ }^{1}$ Erasmus School of Health Policy \& Management, Erasmus University Rotterdam, P.O. Box 1738, 3000 DR Rotterdam, \\ The Netherlands, ${ }^{2}$ Equalis, Jaarbeursplein 6, 3521 AL Utrecht, The Netherlands, ${ }^{3}$ Health Economics and Health Policy at \\ Erasmus School of Health Policy \& Management, Erasmus University Rotterdam, P.O. Box 1738, 3000 DR Rotterdam, The \\ Netherlands and ${ }^{4}$ Health Care Market Regulation at Erasmus School of Health Policy \& Management, Erasmus University \\ Rotterdam, P.O. Box 1738, 3000 DR Rotterdam, The Netherlands \\ *Corresponding author. Email: stolper@eshpm.eur.nl
}

(Received 5 June 2019; revised 1 May 2020; accepted 8 May 2020; first published online 21 July 2020)

\begin{abstract}
In health care systems based upon managed competition, insurers are expected to negotiate with providers about price and quality of care. The Dutch experience, however, shows that quality plays a limited role in insurer-provider negotiations. It has been suggested that this is partly due to a lack of cooperation among insurers. This raises the question whether cooperation amongst insurers is a precondition or a substitute for quality-based competition. To answer this question, we mapped insurers' cooperating activities to enhance quality of care using a six-stage continuum. The first three stages (defining, designing and measuring quality indicators) may enhance competition, whereas the next three stages (setting benchmarks, steering patients and selective contracting) may reduce it. We investigated which types of insurer cooperation currently take place in the Netherlands. Additionally, we organized focus groups among insurers, providers and other stakeholders to examine their perceptions on insurer cooperation. We find that all stakeholders see advantages of cooperation amongst insurers in the first stages of the continuum and sometimes cooperate in this domain. Cooperation in the next stages is almost absent and more controversial because without adequate quality information, it is difficult to assess whether the benefits outweigh the cost associated with reduced competition.
\end{abstract}

Key words: Health insurers; health system evaluation; insurer cooperation; managed competition; quality of care

\section{Introduction}

In countries with a health care system based upon managed competition (e.g. Germany, Switzerland and the Netherlands), insurers are expected to act as prudent buyers of care on behalf of their enrolees. Consumers can choose between competing insurers which are expected to contract high-quality health care at the lowest price possible in order to maintain or increase their market shares.

The Netherlands is widely perceived as a frontrunner in implementing managed competition in health care (Van de Ven et al., 2013). Studying the role of health insurers in the Netherlands could therefore contribute to a deeper understanding of how the model of managed competition works in practice. Several studies find that quality plays a limited role in insurer-provider negotiations and consumer choices in the Dutch health care system [ Nederlandse Zorgautoriteit (NZa), 2014; Ruwaard et al., 2014; van Kleef et al., 2014; Maarse et al., 2016; OECD/European Observatory on Health Systems and Policies, 2017; Holst et al., 2019; Stolper et al., 2019].

(c) The Author(s), 2020. Published by Cambridge University Press. This is an Open Access article, distributed under the terms of the Creative Commons Attribution licence (http://creativecommons.org/licenses/by/4.0/), which permits unrestricted re-use, distribution, and reproduction in any medium, provided the original work is properly cited. 
Two different types of reasons are proposed for this. First, competition between insurers focuses on price rather than quality of care caused by (a combination of) a lack of reliable quality information, a lack of trust in insurers and/or other market imperfections (e.g. inadequate risk adjustment). Second, competition hinders insurers in steering on quality because it counteracts necessary coordination and discourages investments in quality due to potential free-rider problems, while competition regulation (i.e. antitrust law) limits the legal possibilities for cooperation among insurers.

The first type of reasons posits that insurer competition is primarily focused on price, which may change when insurers and consumers become more aware and sensitive to differences in quality of care. When quality improvements result in lower costs, for instance because of better coordination of care or a reduction of unnecessary treatments, this may not be a problem. Such improvements will then be fostered by price competition. However, quality improvements that are associated with higher costs may be impeded when on the health insurance market price, rather than quality differences, is and remains consumers' main choice determinant. The key problem here is that an important precondition for effective quality competition - the presence of comparable and reliable public information on quality - is not yet fulfilled (Van de Ven et al., 2013). Fulfilling this precondition, however, may well require more cooperation among insurers, e.g. by jointly developing and measuring quality indicators and by requiring the same quality information from health care providers. Notice that an extreme way to encourage quality competition is to eliminate the possibility of price competition by regulating prices (Gaynor, 2007). This radical option, however, is beyond the scope of this paper since our study focuses on the current Dutch health care system with insurer-provider price negotiations.

The second type of reasons posits that competition on quality by insurers can be counterproductive. To improve quality, insurers should cooperate rather than compete on quality of care, e.g. by jointly setting quality benchmarks or by jointly investing in quality improvement. If this is true, insurer competition may not only obstruct cooperation on quality improvements that result in higher costs but also those that result in lower costs.

From both reasons, it follows that cooperation between insurers could contribute to more focus on quality, although the extent and type of cooperation is likely to differ. The underlying question is whether insurer cooperation on quality is a precondition for quality-based competition (as suggested by the first reason) or a substitute for it (as suggested by the second reason).

In this paper, we examine (i) how the various stakeholders in the Dutch system of managed competition perceive the need for cooperation among insurers to enhance quality of care, and (ii) whether and how Dutch health insurers currently cooperate to realize better quality of care. To this end, representatives of the following stakeholders were invited to participate in a qualitative study: health insurers, health care providers, patients and the government (i.e. the Ministry of Health Welfare and Sports, the Authority for Consumers \& Markets and the Dutch Healthcare Authority). In addition, we investigated which initiatives are already jointly undertaken by health insurers to enhance quality of care in daily practice.

Our study contributes to the literature by enriching the understanding of health insurers' role and behaviour in a system of managed competition when it comes to enhancing quality of care. Despite the large empirical literature on the relationship between provider competition and quality of care (see for a review of this literature Sivey and Chen, 2019), to date the empirical evidence on the relationship between insurer competition and quality of care is lacking. Hence, the main contribution of our paper is to show (i) how the various stakeholders perceive this relationship and (ii) in which areas they expect cooperation rather than competition might be preferred. The results provide direct insight in the perceptions of the different players within the system. Furthermore, our findings may be relevant for other countries in which insurers or other thirdparty payers play a role in steering on quality of care because they may assist policymakers in these countries to make better informed decisions about whether or not competition and cooperation among payers should be permitted and, if so, under which conditions. 
In the next section, we will discuss the background of the Dutch health care system and the role of competition and cooperation within this system. In the third section, we categorize and rank the various activities by insurers to enhance quality of care, and discuss the pros and cons of insurer cooperation for each type of activity and whether this could be harmful to competition. The fourth section discusses our research methods and the following two sections present the results of our study. In the final section, we reflect on our findings and discuss possible implications.

\section{Background and context}

In 2006, the Netherlands introduced a major health care reform based upon the principles of managed competition. Central to the reform is the notion that private health insurers, competing within public constraints, act as prudent buyers of health care on behalf of their enrolees (Enthoven and van de Ven, 2007). In this system, the government determines a standardized benefit package that insurers are obliged to offer. Selective contracting of health care providers is allowed, as long as insurers guarantee that sufficient care is provided. Once a year, during a six week period, consumers can switch from one insurer to another. Insurers are obliged to accept all applicants (open enrolment) and have to charge the same premium to everyone with the same health plan (community rating). There is a sophisticated system for risk equalization in place that aims to minimize insurers' incentive for risk selection by compensating them ex ante for the different risk profiles of their enrolees (Minister of Health, 2004; Enthoven and van de Ven, 2007; Van de Ven and Schut, 2009). In 2018, there are 23 health insurers active in the Netherlands. These insurers were part of 10 different independent companies. The four largest health insurance companies have a combined market share of $86.5 \%$ [Nederlandse Zorgautoriteit (NZa), 2018].

Competition amongst insurers is considered to be a crucial element of the system as it has to incentivize insurers to offer health plans with the best possible price, quality and service (Van de Ven, 1996). This does, however, not rule out the possibility of cooperation. Under the Dutch Competition Act, which is based on European Competition Law, agreements between undertakings - including health insurers - are prohibited when these "have the intention to or will result in hindrance, impediment or distortion of competition on the Dutch market or on a part thereof". The Dutch Authority for Consumers \& Markets (ACM), who as an independent regulator is responsible for enforcing the rules for fair competition, has confirmed that despite the cartel prohibition, certain forms of cooperation are acceptable in a market-based health care system. As also explained by the ACM, even anticompetitive cooperative agreements may sometimes be allowed. Generally, this will be the case when the direct benefits outweigh the necessary restrictions on competition, a fair share of those benefits is passed on to consumers, and competition is not completely eliminated.

\section{Competition and cooperation on quality}

There is evidence from other markets that cooperation and competition can exist alongside each other in a harmonious way. Bouncken et al. reviewed 89 papers that studied the coexistence of competition and cooperation in different markets and contexts. These cases show that it is possible for competing actors to cooperate on some domains to create value and simultaneously compete on other domains to capitalize on that value (Bouncken et al., 2015). There are, however, no studies of this concept within a health care system based upon the principles of managed competition.

To assess which forms of cooperation by insurers to enhance quality of care would fit in a system of managed competition, we need to identify which types of cooperation are potentially harmful to competition. To do so, we ranked various activities on which cooperation among insurers might be useful to enhance quality of care using a six-stage continuum in which each stage preferably (though not necessarily) requires the activities of the previous one (see Figure 1). 


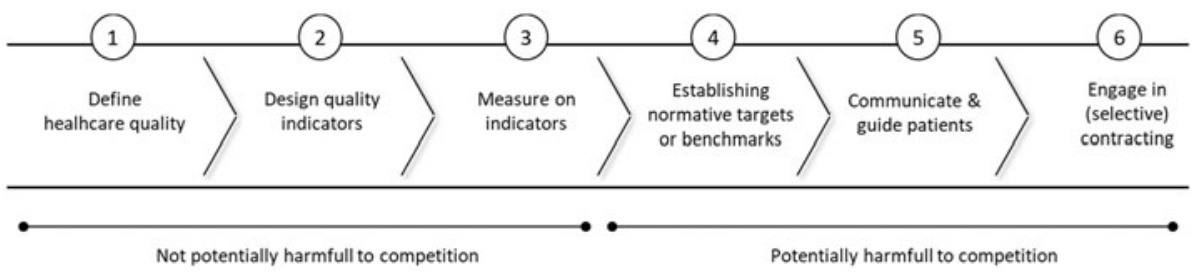

Figure 1. Continuum of activities on which insurers might cooperate to enhance quality of care.

Based upon the Dutch and European competition law and standard enforcement practice (as discussed in Section 2), joint activities by insurers on the first three stages are not seen as potentially harmful to competition. The Dutch competition authority even explicitly stated that these types of cooperation are acceptable and even beneficial for effective competition in the health care system [Nederlandse Mededingingsautoriteit (NMa), 2009]. Perceived advantages of these types of cooperation are increased transparency, lower costs (no redundancy), more coherence and more efficiency through better informed consumer choice.

From stage four onwards, joint activities by insurers to enhance quality may become increasingly harmful to competition. For instance, if insurers jointly decide on selective contracting (stage six), non-contracted providers may be effectively excluded from the market. Jointly establishing benchmarks (stage four) or jointly guiding patients to specific preferred providers (stage five) may also effectively reduce the scope for health care providers to compete. By these joint activities, health insurers may obtain monopsony power, which may eventually reduce quality of care (Herndon, 2002). Hence, cooperation amongst insurers in this area (stage 4-6) could lead to suboptimal outcomes because an important driver to improve quality is neutralized.

On the other hand, cooperation in this area may also have meaningful advantages, such as: (i) the reinforcement of insurers' bargaining power; (ii) a higher willingness among insurers to invest in quality improvement due to a reduction of free-rider problems (given that providers typically do not want to discriminate between patients with different insurer contracts); (iii) more transparency (e.g. uniform benchmarks) and a lower administrative burden (e.g. uniform contracting and registration requirements). Additionally, cooperation could mitigate the reputational risks for insurers that actively try to enhance quality of care by setting benchmarks, steering patients or selective contracting. Reputational risk is found to be a negative incentive for insurers to steer on quality (Stolper et al., 2017). If insurers jointly and simultaneously steer on quality, they share these reputational risks, which may increase their willingness to engage in these activities.

Hence, allowing or encouraging cooperation in this domain requires trade off the potential advantages against the potential disadvantages. In specific guidelines for the health care sector [Nederlandse Mededingingsautoriteit (NMa), 2004; Nederlandse Mededingingsautoriteit (NMa), 2010; Nederlandse zorgautoriteit (NZa), 2010; Autoriteit Consument \& Markt (ACM), 2015a, 2015b, 2015c; Autoriteit Consument \& Markt (ACM), 2016], the Dutch competition authority clarifies that an assessment of the overall effect on consumers is crucial for its decisions whether or not to allow such forms of cooperation. A few cases have indeed been assessed by the competition authority [Autoriteit Consument \& Markt (ACM), 2015a, 2015b, 2015c; Autoriteit Consument \& Markt (ACM), 2016]. An example is the evaluation of an insurers' plan for jointly purchasing emergency care. The competition authority judged that "without independent and well supported quality standards for emergency care, insurers are not able to show that the advantages of concentrating emergency care outweigh the disadvantages for patients" [Autoriteit Consument \& Markt (ACM), 2014]. This judgment shows that the competition authority is willing to make the required trade-off, and thus willing to approve specific forms of cooperation even if they may reduce competition. 


\section{Methods and data analysis}

\subsection{Design, participant recruitment and focus group methodology}

To investigate what insurers, providers and other stakeholders think about cooperation amongst insurers on enhancing quality of care, we organized three different focus groups. One with insurers, one with providers and one with other stakeholders (i.e. representatives from the patient association, the Ministry of Health, and the competition and health care authorities). The aim of the focus group with other stakeholders was to include the perspective of 'third parties'; organizations that do not buy or deliver care but have an interest in the outcome of the contracting process between insurers and providers. We opted for focus groups because of the exploratory nature of our study; we expected that this set up would engender a broad discussion in which opposing and supporting ideas would be debated (Pope et al., 2002).

For the first focus group, we invited the four large insurers and a selection of the small insurers, covering more than $90 \%$ of the Dutch population. For the second focus group, we invited representatives from 13 provider associations representing the most important provider types (e.g. academic and general hospitals, medical specialists, GPs, etc.). Invitations for the third focus group were directed at the national patient association, the Ministry of Health and two regulators (ACM as the competition authority, and NZa as the health care authority). Participants of the focus groups were chosen based upon their position and years of relevant experience. We used snowball sampling to extend the initial list of participants, which was based upon expert selection.

The set-up of the focus groups was semi-structured and the duration was around two hours for each focus group. We designed a question list to structure the focus group discussions (see Appendix 1) but allowed the participants to deviate from these questions. There were two moderators per focus groups, both members of our research team. The other members of our research team were present as observer.

The focus groups also provided a first selection of current examples of cooperation between insurers on quality of care. To complete this list of cases, we performed an additional document scan on the publications of the insurers' procurement policy. These are available on their websites. We searched the documents for key words related to cooperation amongst insurers in order to find new examples of cooperation. To deepen our understanding of the examples found, we organized follow-up telephone interviews with a small selection of the same participants that were invited for the focus groups. We continued this process until no more new examples of cooperation were found.

\subsection{Analysis}

We used the 'thematic network approach' of Attride-Stirling (Attride-Stirling, 2001) for analysis of the data. During the first step, all data from the focus groups was transcribed verbatim. We coded the text, using ATLAS.ti as research software. Prior to the coding process, the research team set up a code book based upon initial assessment of the relevant topics. We applied an iterative and circular method during the coding process in order to adjust or supplement the code book where needed, and to ensure full data saturation. Coding was executed by a team of four researchers that all coded half of the data. In this way, all data was coded twice, each time by a different researcher. Comparison of results and the ensuing discussion produced consensus on the definite codes that were applied to the data. During the next steps, we clustered the codes into broad categories. Continuous analysis and extensive dialogue amongst the researchers provided the basis for the classification in the different categories. To assess the relative importance of all the different notions that emerged, we counted the number of codes and groups of codes for the three groups of participants and for all the stakeholders together. 
After our initial analyses, we performed a member check to improve the internal validity of our study. To do so, we distributed the results of our analyses to the participants of the focus groups. Each participant only received the results of the focus group that he or she participated in. The participants were asked to review our results and to indicate if our representation of their perspective was accurate. In this way, we were able to assess if our interpretation of the perceptions of our participants was correct and complete (Lewis, 2015).

The results of the document scan were directly translated into an overview of current examples of cooperation amongst insurers on quality. This overview was distributed amongst all participants of our focus groups as a second member check. Participants were asked to indicate if the overview was, in their eyes, complete and accurate.

\subsection{Strengths and limitations}

The most important strength of our research is that we studied the perceptions of the participants and combined this with an overview of the current state of affairs. Although perceptions do not always reflect reality, they are very real in their consequences. An additional strength is that our study reflects on the problem from different perspectives, including those of the most important stakeholders. A first possible limitation of our study is that participants might be inclined to use the focus groups to send a message to other stakeholders. In that case, they could have been giving strategic answers to our questions. Because of this reason, we chose not to mix up the different stakeholders in the focus groups. Furthermore, we tried to minimize bias by tailoring our questions towards a system perspective. A second limitation is that not all quality initiatives are described in publicly accessible documents and/or that our participants are not fully aware of all current initiatives to jointly steer on quality. We minimized this risk by carefully selecting participants for the telephone interviews and the second member check, based upon their knowledge of and involvement in quality initiatives. A third possible limitation is that the focus group of providers was composed of people from the various provider associations instead of practising providers. We made this choice because people from these providers associations may be more representative for the large group of providers than a small - potentially biased - selection of practising providers. Nevertheless, we cannot be sure that the opinions of people from provider associations best reflect the (common) opinion of individual providers.

\section{Results of the focus group discussions}

Most invited parties were willing and able to participate in the focus group meetings. The insurer focus group included four participants, representing three of the four large insurers and one small insurer (with a combined market share of 66\%). The provider focus group consisted of six participants from major provider associations. The focus group with other stakeholders consisted of seven participants from the competition authority, health care authority, the Ministry of Health and the national patient association. For the investigation of the current joint initiatives by insurers to enhance quality of care, we scanned 18 publicly accessible procurement policy documents and conducted two telephone interviews. In total, 18 participants representing 15 different organizations participated in our study. Additionally, 10 participants responded to one or both of the member checks.

\subsection{Thematic analysis}

Following the approach outlined above, we identified 11 arguments why insurers should or should not cooperate to improve quality of care. However, some of the arguments against insurer cooperation on quality improvement were not directed at cooperation but rather at insurers interfering with quality as such (regardless of cooperation). We therefore made a distinction between 
Table 1. Arguments why insurers should or should not (cooperate to) improve quality of health care

\begin{tabular}{|c|c|c|}
\hline & Argument & Explanation \\
\hline \multirow[t]{3}{*}{$\begin{array}{l}\text { Arguments for cooperation } \\
\text { on quality by insurers }\end{array}$} & Uniformity & $\begin{array}{l}\text { Cooperation could create uniformity of quality } \\
\text { requirements for providers, i.e. resulting in a reduction } \\
\text { of the administrative burden for health care providers. }\end{array}$ \\
\hline & $\begin{array}{l}\text { Quality } \\
\text { improvement }\end{array}$ & Cooperation could improve quality of care \\
\hline & No competition & Quality of care is not suitable for competition \\
\hline \multirow{3}{*}{$\begin{array}{l}\text { Arguments against } \\
\text { cooperation on quality by } \\
\text { insurers }\end{array}$} & $\begin{array}{l}\text { Diminishes } \\
\text { distinctiveness }\end{array}$ & $\begin{array}{l}\text { Cooperation diminishes the opportunities for insurers to } \\
\text { distinguish themselves }\end{array}$ \\
\hline & Causes delay & $\begin{array}{l}\text { Cooperation can slow down the process of quality } \\
\text { improvement }\end{array}$ \\
\hline & Legal barriers & Legal barriers prevent cooperation on quality by insurers \\
\hline \multirow[t]{5}{*}{$\begin{array}{l}\text { Arguments against } \\
\text { interference on quality by } \\
\text { insurers }\end{array}$} & Inappropriate use & $\begin{array}{l}\text { Insurers inappropriately use quality information as a } \\
\text { contracting instrument instead of as an instrument to } \\
\text { improve quality of care }\end{array}$ \\
\hline & Lack of knowledge & Insurers lack the knowledge to steer on quality of care \\
\hline & Market not ready & $\begin{array}{l}\text { There are too many barriers in the market (e.g. lack of } \\
\text { transparency on quality of care) that need to be solved } \\
\text { first }\end{array}$ \\
\hline & Inappropriate role & It is not the role of the insurers to steer on quality \\
\hline & $\begin{array}{l}\text { Damages } \\
\text { reputation }\end{array}$ & $\begin{array}{l}\text { Interfering with quality of health care as such damages } \\
\text { the reputation of insurers }\end{array}$ \\
\hline
\end{tabular}

arguments for and against insurer cooperation on quality and arguments against insurer interference with quality. Table 1 provides an overview of the identified arguments.

For each focus group, Table 2 provides an overview of the relative frequencies with which the different arguments were mentioned by the participants. The overall picture is that the different stakeholders have different viewpoints when it comes to interference on quality and cooperation. Health insurers are clearly more positive about cooperation and interference than the other stakeholders. Providers - and to a lesser extent the other stakeholders - raised very few arguments against cooperation but oscillated between arguments for cooperation and arguments against quality interference as such.

\subsection{Arguments in favour of cooperation}

All focus groups extensively discussed arguments for cooperation. Table 3 provides a detailed overview of the frequency in which the various arguments were mentioned by each group. As this table shows, uniformity of standards is by far the most frequently mentioned argument in favour of cooperation. Most providers currently experience that individual insurers have their own perspective on quality and develop their own concepts and projects to improve quality. The resulting variety and multitude in quality requirements bothers providers. In the words of one of the participants:

"Every insurance company has its own toy, its own thing. There is no coordination whatsoever

(...) everyone has its own project" - participant 10 (provider focus group).

The idea is that cooperation amongst insurers could create more uniformity of quality requirements and initiatives. In this way, providers do not have to deal with an unmanageable variety of 
Table 2. Relative frequencies in which categories of arguments were mentioned per focus group (in percentages and total also in absolute numbers)

\begin{tabular}{lccccc}
\hline Focus group & $\begin{array}{c}\text { Arguments for } \\
\text { cooperation }\end{array}$ & $\begin{array}{c}\text { Arguments } \\
\text { against } \\
\text { cooperation }\end{array}$ & $\begin{array}{c}\text { Arguments } \\
\text { against } \\
\text { interference }\end{array}$ & $\begin{array}{c}\text { Total } \\
\text { percentage }\end{array}$ & $\begin{array}{c}\text { Total \# of } \\
\text { quotes }\end{array}$ \\
\hline Insurers & 65 & 22 & 13 & 100 & 86 \\
Providers & 45 & 9 & 55 & 100 & 55 \\
\hline Other stakeholders & 35 & 15 & 36 & 100 & 34 \\
\hline Mean & 49 & 15 & 100 & 175 \\
\hline
\end{tabular}

Table 3. Relative frequencies in which arguments were mentioned (in percentages)

\begin{tabular}{|c|c|c|c|c|c|}
\hline & Arguments & Insurers & Providers & $\begin{array}{c}\text { Other } \\
\text { stakeholders }\end{array}$ & Mean \\
\hline \multirow[t]{4}{*}{ For cooperation } & Uniformity of standards & 28 & 38 & 29 & 32 \\
\hline & Quality improvement & 22 & 7 & 3 & 11 \\
\hline & No competition & 15 & 0 & 3 & 6 \\
\hline & Total & 65 & 45 & 35 & 49 \\
\hline \multirow{4}{*}{$\begin{array}{l}\text { Against } \\
\text { cooperation }\end{array}$} & Causes delay & 3 & 0 & 0 & 1 \\
\hline & Diminishes distinctiveness & 7 & 0 & 6 & 4 \\
\hline & Legal barriers & 12 & 9 & 9 & 10 \\
\hline & Total & 22 & 9 & 15 & 15 \\
\hline \multirow{5}{*}{$\begin{array}{l}\text { Against } \\
\text { interference }\end{array}$} & Inappropriate use & 0 & 16 & 0 & 5 \\
\hline & Damages reputation & 7 & 0 & 6 & 4 \\
\hline & Market not ready & 0 & 9 & 35 & 15 \\
\hline & Role uncertainty & 6 & 20 & 9 & 12 \\
\hline & Total & 13 & 45 & 50 & 36 \\
\hline
\end{tabular}

approaches but can work together with all insurers in a single integrated approach to improve quality of care. Especially providers emphasized this argument, which does not come as a surprise because they are most troubled by the current lack of coordination. However, insurers and other stakeholders also came up with this argument. They recognize the limitation of the current way of working and acknowledge that cooperation could have beneficial effects for all parties involved. Additionally, they made the argument that uniformity could be more efficient because duplicity ('reinventing the wheel') could be avoided.

Apart from uniformity, especially insurers see various other reasons why they should cooperate. Two arguments were broadly discussed during their focus group: quality improvement and the non-competitive nature of quality of care. The first argument concerns the idea that cooperation amongst insurers would in the end lead to better quality of care. The participating insurers expressed a sincere belief that cooperation would speed up the process of quality improvement. The second argument that some insurers brought forward is that quality of care is not something that is suitable to compete on. Quality of contracted care is in their view not a parameter that consumers include in their health plan choice, and providers are not willing to differentiate quality of care depending on the health plan chosen by their patients. Apart from that, insurers also express uneasiness themselves with the idea of competition on quality of care. They feel that 
improvements of quality of care should be beneficial for all patients and not only for their own customers. Hence, improving quality of care is not primarily done for competitive advantages but for the benefit of all:

"It has social relevance, so it is not something you want to compete on until the very end" participant 4 (insurer focus group).

\subsection{Arguments against cooperation}

We find that especially insurers mention arguments against cooperation (see Table 3), while providers and other stakeholders focus more on arguments against interference with quality as such (which we will discuss in Section 5.4). Insurers mention three different reasons against cooperation. The most important drawback of cooperation that insurers - and to a lesser extent providers and other stakeholders - perceive is the legal uncertainty about what types of cooperation will (not) be allowed by the competition authority. Insurers argue that in daily practice, this uncertainty poses a significant barrier because the competition authority does not provide clear and unambiguous answers about the acceptability of initiatives to cooperate. This is why insurers refrain to cooperate in practice:

They (regulators, ed.) never provide clarity. That is the whole problem. In fact they say: "Sure, you can cooperate. But if a healthcare provider makes an objection, we don't know what will happen". They simplify the whole thing, that's the point - participant 3 (insurer focus group).

Providers added that they sometimes feel that insurers use this argument as an excuse for the lack of cooperation:

"I think that many obstacles - whether they are real or not - are being sought in anti-competitive legislation" - participant 7 (provider focus group).

The argument that cooperation may diminish insurers' distinctiveness and therefore their incentives to improve quality of care was only marginally discussed. Insurers and other stakeholders mentioned the argument but did not reflect extensively on the idea. Therefore, this does not seem to be perceived as a strong argument against cooperation.

\subsection{Arguments against interference}

When asked why insurers should not cooperate, providers and other stakeholders frequently offered arguments against insurers' interference with quality as such (see Table 3 for frequencies). Most of the time, this shift of focus happened without participants explicitly recognising this.

For several participants from the provider group, the main reason for their objections against attempts by insurers to enhance quality of care is that they perceive this - almost by definition as an inappropriate role for insurers. In their view, quality of care is something that concerns medical professionals and insurers have no part in it:

"The question is whether the health insurer should interfere with creating outcome indicators.

That is something that medical professionals should do" - participant 7 (provider focus group).

Additionally, several participants of the provider group expressed fear that insurers will inappropriately use quality information as a contracting instrument. For these participants, this has nothing to do with improving quality of care: 
"Being judged on indicators that say little about good care, but more about whether you have met certain values. That is what is happening" - participant 6 (provider focus group).

Participants from the group with other stakeholders also raised arguments against quality interference by insurers as such, although based on a different notion. In their perception, the market is not yet ready for insurers to steer on quality because important preconditions need to be fulfilled before insurers can effectively fulfil this role. The most important condition mentioned is transparency of quality. They argued that only when there is consensus on and access to reliable quality information, insurers can effectively steer on quality of care.

\section{Results of the inventory of insurer cooperation}

In addition to our investigation of the perceptions of various stakeholders, we also examined whether and how insurers actually cooperate in enhancing quality of care. Based upon the discussions in the focus groups, a scan and analysis of available procurement policy documents, and a subsequent check and feedback by participants from the focus groups, we identified 14 initiatives in which health insurers currently (intend to) cooperate to enhance quality of care. Figure 2 provides an overview of these initiatives plotted on the continuum of (joint) activities to enhance quality of care that we discussed in Section 2. Appendix 2 provides a more detailed overview of all identified initiatives. Please note that these initiatives are sometimes developed in close collaboration with the health care providers.

Most initiatives are part of the first stages in the continuum, either focusing on developing quality indicators (five initiatives) or on developing and measuring quality indicators (also five initiatives). We found only four initiatives that aim to go further (stage 4-6), by jointly establishing normative targets, guiding patients and/or engaging in selective contracting. From these initiatives, only one is actually realized. This initiative still largely focuses on the first three stages but also includes stage four since it establishes benchmarks.

The other three initiatives involve the most extensive forms of cooperation and all aim at a concentration of expensive and complex treatments. None of these three initiatives have been implemented yet and all have been subject to uncertainty about legal acceptability. In the first case - concerning emergency care - the competition authority unilaterally decided to publish a negative evaluation of the proposed insurer cooperation. The main argument was that insurers could not substantiate the claimed benefits of the concentration with adequate quality data and missed support of the medical scientific associations [Autoriteit Consument \& Markt (ACM), 2014]. In the case of proton therapy, the insurers requested an informal judgment of their intention to jointly contract only one provider instead of separately negotiating terms with the four providers that intended to invest in proton therapy. Their most important argument was more cost- than quality driven and stated that separate negotiations would result in excess capacity of this expensive treatment in the Dutch market. The competition authority could not find confirmation for this argument, concluded that the disadvantages outweighed the advantages and decided against it [Autoriteit Consument \& Markt (ACM), 2015a, 2015b, 2015c]. In the case of the proposed insurer cooperation on concentrating prostate cancer treatments, the competition authority judged that it was not able to evaluate the proposal because the plan for cooperation was in a too early stage of development (Skipr, 2017). The request for an informal judgement was made by only one insurer and the authority found too little support for the plan amongst other insurers and also observed that there was insufficient information available to weigh the advantages against the disadvantages.

Hence, from the perspective of quality enhancement, there are so far no examples of the most extensive forms of cooperation that received a positive evaluation of the competition authority based upon the criteria discussed in Section 2. 


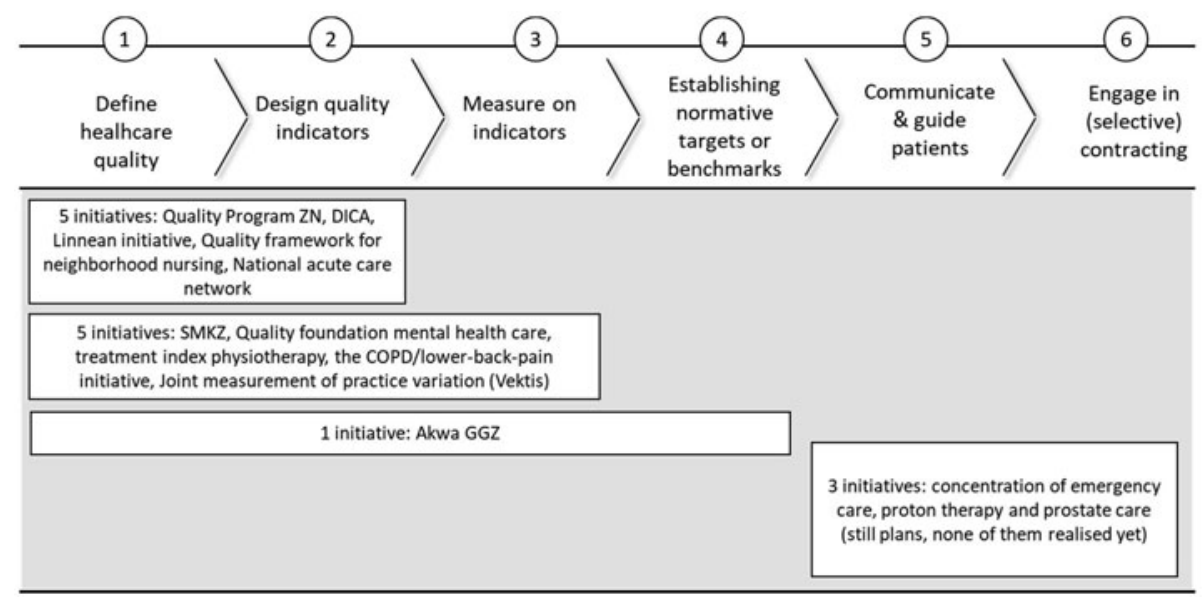

Figure 2. Number and examples of initiatives in which insurers cooperate to enhance quality of care plotted on the continuum of joint activities

\section{Discussion}

The current Dutch health care system provides an interesting setting to evaluate the model of managed competition, given that in the Netherlands most preconditions for this model seem to be fulfilled (Van de Ven et al., 2013). In this system, competition should incentivize insurers to contract high quality of care at the lowest price possible. To date, however, competition among insurers is primarily focused on price, while insurers' efforts to enhance quality of care have been limited. The implications of several studies suggest that for several reasons, cooperation among insurers could be an effective way to increase the role of quality of care in the contracting process between insurers and providers [Nederlandse Zorgautoriteit (NZa), 2014; Ruwaard et al., 2014; van Kleef et al., 2014; Maarse et al., 2016; OECD/European Observatory on Health Systems and Policies, 2017; Stolper et al., 2017]. An unanswered question, however, is what this cooperation should entail and whether this would be consistent or in conflict with the model of managed competition. In our study, we sought to find out how the various stakeholders in the system perceive the need for cooperation among insurers on quality of care and whether and how insurers currently cooperate.

\subsection{Key lessons}

We found that all stakeholders see advantages of cooperation amongst insurers on quality of care. These advantages focus mainly on the first three stages (define, design and measure quality indicators) of the continuum of activities that insurers may employ to enhance quality of care (see Figure 1). The main argument in favor of cooperation in these domains is uniformity. All stakeholders acknowledge that quality improvement in health care is troubled by the variety of initiatives that different insurers developed to enhance quality of care. Stakeholders perceive less advantages with respect to the other domains in which insurers can cooperate (i.e. establishing benchmarks, communicate to patients and engage in selective contracting). Only some insurers think that more extensive forms of cooperation are desirable to enhance quality of care.

None of the involved stakeholders were very outspoken on arguments against insurer cooperation. Some insurers mentioned that cooperation could diminish the possibilities to discern themselves amongst each other and others indicated that competition legislation could be a reason not to cooperate. The other stakeholders have the perception that the market is not ready for interference on quality by health insurers, thereby implicating that cooperation on quality is also not feasible at the moment. 
In addition, we saw that providers are generally not supportive of the idea that insurers will steer on quality. They question whether insurers are rightly positioned to have a role in quality improvement and fear that insures will misuse activities to enhance quality for financially driven contract negotiations.

In total, we found 11 initiatives in which insurers actually do cooperate. Almost all these initiatives focus on jointly developing and measuring quality indicators. Further forms of cooperation are either in an early stage of development or simply absent. Moreover, the few proposed initiatives concerning more extensive forms of insurer cooperation were negatively evaluated in a preliminary assessment by the competition authority. The absence of more extensive forms of cooperation is in line with the finding from the focus groups that stakeholders are mainly positive about the first three stages of cooperation and see no (active) role for insurers to interfere on quality as such.

\subsection{Interpretation and implications}

Our findings thus indicate that insurer cooperation focusing on the first three stages of the cooperation continuum is undisputed and largely accepted. We have seen that most of the cooperation that currently exists takes place in this domain. Moreover, all stakeholders bring in positive arguments for cooperation in this domain and the negative arguments that were mentioned are not applicable: there are no legal barriers for jointly developing quality indicators and it is not logical for insurers to seek distinction on the definition of quality or the indicators used. Hence, insurer cooperation in this domain appears to be a precondition for more effective competition on quality. The only real obstacle for successful cooperation in this domain is the low level of trust. Various recent studies confirm our finding that among both providers and consumers trust in Dutch health insurers is rather low (Bes et al., 2013; Maarse and Jeurissen, 2019).

Cooperation on stage 4-6 of the continuum, in which quality standards are set and patients are steered towards preferred or selected providers, appears to be more controversial. We found that there is hardly any cooperation in this domain and those initiatives that we did find are in their infancy. Furthermore, we saw that these initiatives were critically evaluated by the competition authority, which supports the argument by the stakeholders that more extensive forms of cooperation may encounter legal barriers. This does not rule out the possibility, however, that the benefits of more extensive insurer cooperation outweigh the disadvantage of a reduction of competition. But the burden of proof is on the insurers. However, the problem is that this proof is hard to deliver without adequate quality information. Therefore, the question to what extent insurer cooperation could be an effective substitute for competition cannot be answered yet.

Hence, the prospects of any initiative on cooperation amongst insurers beyond the first three stages of the continuum will be indeterminate without meaningful, reliable and accessible quality information. This means that simple forms of cooperation to achieve this kind of quality information are not only beneficial for enhancing quality of care, but also necessary to achieve the right balance between competition and more extensive forms of insurer cooperation on quality of care. As long as providers object against any interference by insurers to improve quality of care, however, even insurer cooperation on developing and measuring uniform quality indicators is bound to fail.

For policymakers, this implies that improving transparency of quality should have a high priority. During the past decade, however, efforts to increase transparency of quality show that the development and implementation of uniform quality standards and indicators proves to be a difficult and prolonged process. The development of a common set of quality indicators is not a typically Dutch challenge but a more broad phenomenon and it can be seen as an important caveat for competition on quality of care (Barros et al., 2016). However, without strong institutional support, insurers will clearly have a difficult time gaining relevant and reliable quality information from providers, who are in many cases the source of essential data as well as reluctant to share this with the insurers who they view as their opponents. Hence, policymakers should do 
everything within their power to ensure that all stakeholders cooperate in developing a uniform set of meaningful and reliable quality indicators. Only if that point is reached, we may be able to assess whether intensified cooperation amongst insurers is a precondition or substitute for competition.

Acknowledgement. The authors thank Philine Toet for her research assistance.

Conflict of interest. Karel Stolper was employed at CZ Groep at the time of the study. This research, however, was conducted independently outside the employment of CZ Groep but with their consent.

\section{References}

Attride-Stirling J (2001) Thematic networks: an analytic tool for qualitative research. Qualitative research 1, 385-405.

Autoriteit Consument \& Markt (ACM) (2014) ACM wijst zorgverzekeraars op mededingingsrisico bij uitvoering gezamenlijke plannen spoedeisende zorg. Retrieved 11-04, 2019, Available at https://www.acm.nl/nl/publicaties/publicatie/13132/ ACM-wijst-zorgverzekeraars-op-mededingingsrisico-bij-uitvoering-gezamenlijke-plannen-spoedeisende-zorg.

Autoriteit Consument \& Markt (ACM) (2015a) ACM ziet kansen voor centra voor protonentherapie voor behandeling kanker. Retrieved 13-04, 2019, Available at https://www.acm.nl/nl/publicaties/publicatie/13929/ACM-ziet-kansen-voor-centravoor-protonentherapie-voor-behandeling-kanker.

Autoriteit Consument \& Markt (ACM) (2015b) Informele Zienswijze Gezamenlijk Inkopen Door Zorgverzekeraars van Protonentherapie. Den Haag: ACM.

Autoriteit Consument \& Markt (ACM) (2015c) Informele Zienswijze Protonentherapie. Den Haag: ACM.

Autoriteit Consument \& Markt (ACM) (2016) Leidraad Gezamenlijke Inkoop Geneesmiddelen Voor de Medischspecialistische Zorg. Den Haag: ACM.

Barros PP, Brouwer WB, Thomson S and Varkevisser M (2016) Competition among health care providers: helpful or harmful?. The European Journal of Health Economics 17, 229-233.

Bes RE, Wendel S, Curfs EC, Groenewegen PP and de Jong JD (2013) Acceptance of selective contracting: the role of trust in the health insurer. BMC Health Services Research 13, 375.

Bouncken RB, Gast J, Kraus S and Bogers M (2015) Coopetition: a systematic review, synthesis, and future research directions. Review of Managerial Science 9, 577-601.

Enthoven AC and van de Ven WP (2007) Going Dutch - managed-competition health insurance in the Netherlands. New England Journal of Medicine 357, 2421-2423.

Gaynor M (2007) Competition and quality in health care markets. Foundations and Trends ${ }^{\circ}$ in Microeconomics 2, 441-508. Herndon JB (2002) Health insurer monopsony power: the all-or-none model. Journal of Health Economics 21, 197-206.

Holst L, Brabers AEM and Jong JD (2019) 8\% van de verzekerden geeft aan te zijn overgestapt van zorgverzekeraar in 2019. Utrecht, Nivel.

Lewis S (2015) Qualitative inquiry and research design: choosing among five approaches. Health Promotion Practice 16, $473-$ 475.

Maarse H and Jeurissen P (2019) Low institutional trust in health insurers in Dutch health care. Health Policy 123, 288-292.

Maarse H, Jeurissen P and Ruwaard D (2016) Results of the market-oriented reform in the Netherlands: a review. Health Economics Policy and Law 11, 161-178.

Minister of Health (2004) Explanatory Memorandum Health Insurance Act. Den Haag: Sdu Uitgevers.

Nederlandse Mededingingsautoriteit (NMa) (2004) Visiedocument Inkoopmacht. Den Haag: NMa.

Nederlandse Mededingingsautoriteit (NMa) (2009) Individueel en Collectief Onderhandelen Tussen Vrijgevestigde Extramurale Zorgaanbieders en Verzekeraars. Visiedocument NMa. Den Haag: NMa.

Nederlandse Mededingingsautoriteit (NMa) (2010) Richtsnoeren Voor de Zorgsector. Den Haag: NMa.

Nederlandse zorgautoriteit (NZa) (2010) Visiedocument Inkoopmacht en Collectief Onderhandelen. Utrecht: NZa.

Nederlandse Zorgautoriteit (NZa) (2014) Monitor en Beleidsbrief Zorginkoop. Utrecht: NZa.

Nederlandse Zorgautoriteit (NZa) (2018) Monitor Zorgverzekeringen 2018. Utrecht: NZa.

OECD/European Observatory on Health Systems and Policies (2017) Netherlands: Country Health Profile 2017. State of Health in the EU.

Pope C, van Royen P and Baker R (2002) Qualitative methods in research on healthcare quality. Quality and Safety in Health Care 11, 148-152.

Ruwaard S, Loozen E, Struijs J and Polder J (2014) Hoe kopen zorgverzekeraars in bij ziekenhuizen. Een analyse van de contracten tussen verzekeraars en ziekenhuizen. TPEdigitaal 8, 98-117.

Sivey P and Chen Y (2019) Competition and Quality in Healthcare. Oxford Research Encyclopedia of Economics and Finance. Skipr (2017) Gezamenlijke inkoop prostaatkankerzorg in de ijskast. Retrieved 14-15-2019, Available at https://www.skipr.nl/ actueel/id31255-gezamenlijke-inkoop-prostaatkankerzorg-in-de-ijskast.html. 
Stolper K, Boonen L, Schut F and Varkevisser M (2017) Managed competition in the Netherlands: do insurers have incentives to steer on quality? Working paper.

Stolper KC, Boonen LH, Schut FT and Varkevisser M (2019) Managed competition in the Netherlands: do insurers have incentives to steer on quality? Health Policy 123, 293-299.

Van de Ven W (1996) Market-oriented health care reforms: trends and future options. Social Science \& Medicine 43, 655-666.

Van de Ven WP and Schut FT (2009) Managed competition in the Netherlands: still work-in-progress. Health Economics 18, 253-255.

Van de Ven WP, Beck K, Buchner F, Schokkaert E, Schut FE, Shmueli A and Wasem J (2013) Preconditions for efficiency and affordability in competitive healthcare markets: are they fulfilled in Belgium, Germany, Israel, the Netherlands and Switzerland? Health Policy 109, 226-245.

van Kleef R, Schut E and van de Ven W (2014) Evaluatie Zorgstelsel en Risicoverevening. Acht jaar na invoering Zorgverzekeringswet: succes verzekerd?.

\section{Appendix}

\section{Appendix 1: Questioning route focus groups}

\section{Opening}

1) Some remarks on objective study

2) Introduction of participants

3) Explanation of the proceedings of the focus group

4) Opening question: can you give a short statement on cooperation between insurers on quality of care?

\section{Key questions}

1) Current situation: how does cooperation amongst insurers on quality of care currently look like?

a. How and where do insurers currently cooperate on quality of care?

b. How does this cooperation look like - does it differ per segment?

c. What are the motives for this cooperation - do they differ per segment?

2) Advantages and disadvantages: what are the consequences of cooperation amongst insurers on quality of care?

a. What are the implications of cooperation amongst insurers on the health care system in general in specifically with regard to quality?

b. What are the most important advantages of cooperation amongst insurers on quality of care?

c. What are the most important disadvantages of cooperation amongst insurers on quality of care?

d. Do the advantages of cooperation amongst insurers on quality of care outweigh the disadvantages (or the other way around)? Why?

3) Obstacles: what obstacles are there for insurers that intent to cooperate on quality of care?

a. Where and why are these obstacles experienced?

b. Should these obstacles be taken away?

4) Future: what will and/or should change when it comes to cooperation amongst insurers on quality of care?

a. Is the current balance between cooperation amongst and competition between insurers on quality of care the right balance?

b. Would more cooperation amongst insurers have a positive impact on quality of health care?

\section{Closing}

1) Are there any final remarks?

2) Some remarks on next steps and follow up 
Appendix 2: Overview of identified initiatives in which insurers currently cooperate on quality of care

\begin{tabular}{|c|c|c|c|}
\hline Initiative & $\begin{array}{l}\text { Number of insurers } \\
\text { involved }\end{array}$ & Explanation & Phase \\
\hline Quality Program & $\begin{array}{l}\text { Dutch Association for } \\
\text { Health Insurers (23) }\end{array}$ & $\begin{array}{l}\text { The Quality Program focuses on the } \\
\text { development of transparent quality } \\
\text { indicators (the transparency calendar). } \\
\text { Within this Program the Dutch } \\
\text { Association for Health Insurers works } \\
\text { together with other actors (health care } \\
\text { providers and patients) within health } \\
\text { care. One of the themes inside this } \\
\text { program is the development of } \\
\text { questionnaires (PREM) for patients to } \\
\text { share their experience with treatments. } \\
\text { The objective of the program is for } \\
\text { insurers to collaborate on developing } \\
\text { quality indicators }\end{array}$ & $1-2$ \\
\hline DICA & $\begin{array}{l}\text { Dutch association for } \\
\text { Health insurers }\end{array}$ & $\begin{array}{l}\text { DICA offers insight into the quality of care } \\
\text { with reliable comparisons and analyses. } \\
\text { DICA facilitates } 22 \text { registrations for } \\
\text { multiple disciplines and various } \\
\text { disorders. In recent years, the Dutch } \\
\text { association for Health Insurers funded } \\
\text { the (further) development, maintenance } \\
\text { and management of registrations. } \\
\text { Hospitals therefore pay for no longer for } \\
\text { registrations themselves. DICA is } \\
\text { currently focusing on the registrations } \\
\text { within the hospitals. DICA is also } \\
\text { developing PROMs within the DICA } \\
\text { registrations in collaboration with both } \\
\text { insurers and patients }\end{array}$ & $1-2$ \\
\hline Linnean initiative & $\begin{array}{l}\text { Dutch association for } \\
\text { health insurers and } \\
\text { individual health } \\
\text { insurers }\end{array}$ & $\begin{array}{l}\text { National initiative where insurers } \\
\text { participate together with other actors to } \\
\text { develop outcome indicators }\end{array}$ & $1-2$ \\
\hline $\begin{array}{l}\text { Quality framework for } \\
\text { neighbourhood } \\
\text { nursing }\end{array}$ & $\begin{array}{l}\text { Dutch association for } \\
\text { Health insurers }\end{array}$ & $\begin{array}{l}\text { The Dutch association for Health insurers } \\
\text { has participated in the Steering Group } \\
\text { Quality Framework for neighbourhood } \\
\text { nursing. The quality framework aims to } \\
\text { provide direction to the development of } \\
\text { neighbourhood nursing and provide } \\
\text { insight into what good neighbourhood } \\
\text { nursing means }\end{array}$ & $1-2$ \\
\hline $\begin{array}{l}\text { National acute care } \\
\text { network }\end{array}$ & $\begin{array}{l}\text { Dutch association for } \\
\text { Health insurers }\end{array}$ & $\begin{array}{l}\text { Together with } 10 \text { other actors the Dutch } \\
\text { association for Health insurers } \\
\text { developed a quality framework for the } \\
\text { emergency care chain }\end{array}$ & $1-2$ \\
\hline $\begin{array}{l}\text { Quality Assurance } \\
\text { Monitoring } \\
\text { Foundation (SKMZ) }\end{array}$ & 5 & $\begin{array}{l}\text { This foundation aims to develop audit } \\
\text { models within the paramedical sector. } \\
\text { Also new audit and other models and } \\
\text { instruments for the measurement of } \\
\text { quality are developed and used for both }\end{array}$ & $1-3$ \\
\hline
\end{tabular}


(Continued.)

\begin{tabular}{|c|c|c|c|}
\hline Initiative & $\begin{array}{c}\text { Number of insurers } \\
\text { involved }\end{array}$ & Explanation & Phase \\
\hline & & $\begin{array}{l}\text { physiotherapy and other types of care } \\
\text { within the paramedical sector. Several } \\
\text { health insurers are involved in this } \\
\text { process }\end{array}$ & \\
\hline $\begin{array}{l}\text { Quality foundation } \\
\text { mental health care }\end{array}$ & 4 & $\begin{array}{l}\text { The foundation identifies quality indicators } \\
\text { within mental health care (basis GGZ) } \\
\text { and measures, analyses and enriches } \\
\text { data in order to provide insurers and } \\
\text { providers with accurate quality data }\end{array}$ & $1-3$ \\
\hline $\begin{array}{l}\text { Physio-therapy } \\
\text { treatment index }\end{array}$ & 5 & $\begin{array}{l}\text { The treatment index compares the average } \\
\text { number of sessions per client of a } \\
\text { provider with the expected number of } \\
\text { sessions per client based on the client } \\
\text { mix. Insurers involved within the Quality } \\
\text { Assurance Monitoring Foundation made } \\
\text { agreements about further } \\
\text { standardization of the treatment index }\end{array}$ & $1-3$ \\
\hline $\begin{array}{l}\text { COPD and lower back } \\
\text { pain }\end{array}$ & 2 & $\begin{array}{l}\text { Two health insurers developed uniform, } \\
\text { supported sets of outcome indicators to } \\
\text { create transparency in the quality } \\
\text { information of physiotherapy when it } \\
\text { comes to COPD and lower back pain }\end{array}$ & $1-3$ \\
\hline $\begin{array}{l}\text { Joint measurement of } \\
\text { practice variation } \\
\text { (Vektis) }\end{array}$ & $\begin{array}{l}\text { Dutch association for } \\
\text { Health insurers }\end{array}$ & $\begin{array}{l}\text { Based on the national claims database } \\
\text { from Vektis, the Dutch association for } \\
\text { Health insurers studies practice variation } \\
\text { between health care providers }\end{array}$ & $1-3$ \\
\hline Akwa GGZ & $\begin{array}{l}\text { Dutch association for } \\
\text { Health insurers }\end{array}$ & $\begin{array}{l}\text { The Dutch association for Health insurers is } \\
\text { part of the Akwa quality council GGZ. } \\
\text { The quality institute originated from the } \\
\text { GGZ Quality Foundation and the } \\
\text { Foundation Benchmark GGZ. This } \\
\text { institute for quality is involved in the } \\
\text { further development of Routine } \\
\text { Outcome Monitoring (ROM). Akwa GGZ } \\
\text { aims to improve the quality of mental } \\
\text { health care by developing quality } \\
\text { standards, quality indicators and } \\
\text { measuring instruments }\end{array}$ & $1-4$ \\
\hline $\begin{array}{l}\text { Emergency care } \\
\text { concentration }\end{array}$ & $\begin{array}{l}\text { Dutch association for } \\
\text { Health insurers }\end{array}$ & $\begin{array}{l}\text { Health insurers made plans to jointly } \\
\text { concentrate the emergency care to } \\
\text { improve the efficiency. The ACM has not } \\
\text { allowed this cooperation yet, because } \\
\text { health insurers were not able to show } \\
\text { that the benefits of the concentration } \\
\text { outweigh the loss of providers }\end{array}$ & $5-6$ \\
\hline Proton therapy & 8 & $\begin{array}{l}\text { Health insurers asked the ACM for } \\
\text { permission to contract only one } \\
\text { institution providing proton therapy. The } \\
\text { ACM has not given permission because } \\
\text { the most important argument pro } \\
\text { (overcapacity) could not be confirmed } \\
\text { which implied that there were no } \\
\text { benefits that could outweigh the } \\
\text { disadvantages }\end{array}$ & $5-6$ \\
\hline
\end{tabular}


(Continued.)

\begin{tabular}{lll}
\hline Initiative & $\begin{array}{c}\text { Number of insurers } \\
\text { involved }\end{array}$ & \multicolumn{1}{c}{ Explanation } \\
\hline Prostate Cancer & $\begin{array}{l}\text { One health insurer asked the ACM if it was } \\
\text { possible to provide prostate cancer care } \\
\text { in cooperation with other insurers with } \\
\text { the aim to concentrate the care in two or } \\
\text { three institutions. The ACM judged that it } \\
\text { was not able to evaluate the proposal } \\
\text { because the plan for cooperation was in } \\
\text { a too early stage of development }\end{array}$ \\
\hline
\end{tabular}

Cite this article: Stolper KCF, Boonen LHHM, Schut FT, Varkevisser M (2021). Cooperation amongst insurers on enhancing quality of care: precondition or substitute for competition? Health Economics, Policy and Law 16, 273-289. https://doi.org/ $10.1017 /$ S1744133120000195 